\title{
Proefschrift
}

\section{Developments in veterinary medical education - intentions, perceptions, learning processes and outcomes}

Jaarsma ADC. Developments in veterinary medical education - intentions, perceptions, learning processes and outcomes. Universiteit Utrecht, 30 oktober 2008. Promotoren: prof. dr. P. van Beukelen (Utrecht) en prof. dr. A.J.J.A. Scherpbier (Maastricht); co-promotoren: dr. D.H.J.M. Dolmans (Maastricht) en A.M.M. Muijtjens (Maastricht). 152 pagina's. ISBN: 978-90-3934904-5. E-mail: a.d.c.jaarsma@.uu.nl

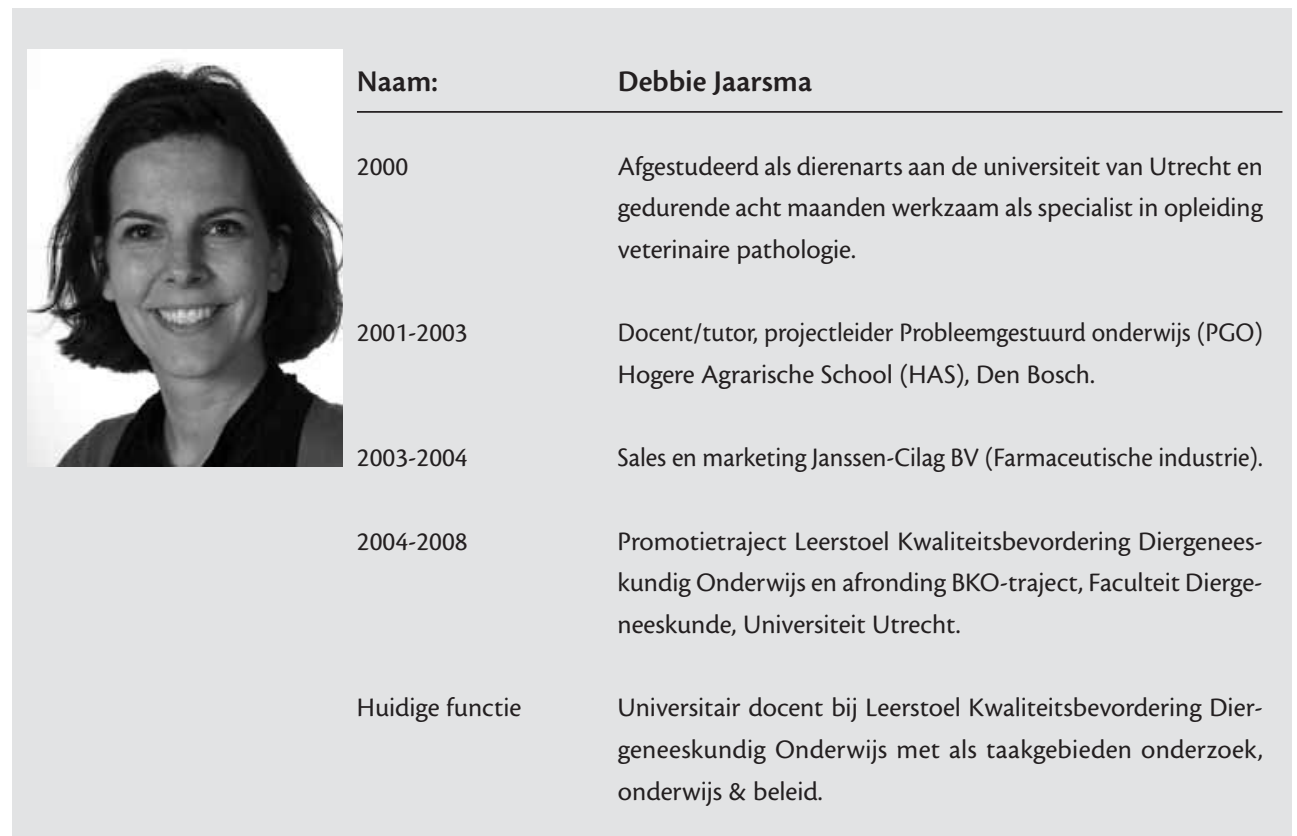

\section{Inleiding}

Ruim twee decennia geleden werden wereldwijd voorstellen voor vernieuwingen gedaan in de diergeneeskunde als professie en in het diergeneeskundig onderwijs in het bijzonder. De voorstellen kwamen neer op: meer studentgecentreerd onderwijs en meer aandacht voor de niet-veterinair technische aspecten van de beroepsuitoefening zoals sociale, communicatieve en academische vaardigheden en levenslang leren. Doelstelling hierbij was het aansluiten bij veranderende maatschappelijke en professionele ontwikkelingen. Deze documenten vormden de aanzet tot wereldwijde onderwijsvernieuwingen. 
Voor de Faculteit Diergeneeskunde van de Universiteit Utrecht was dit aanleiding om curriculumvernieuwingen (Curriculum 1995 en Curriculum 2001) in gang te zetten waarbij een studentgecentreerde aanpak werd verkozen. Thema's die centraal stonden bij de vernieuwingen waren: actief leren in kleinschalig onderwijs (werkcolleges) op basis van opdrachten of problemen, zelfwerkzaamheid, onderzoeksstage als middel voor het bereiken van academische vaardigheden bij studenten en generieke competenties, zoals sociale, communicatieve en managementvaardigheden die van belang zijn voor succes in de latere veterinaire beroepsuitoefening.

De ontwikkelingen in het diergeneeskundige onderwijs lijken sterk op die in het medisch onderwijskundige veld.

\section{Onderzoeksthema's}

Omdat dit promotietraject het eerste was binnen de diergeneeskunde op het gebied van onderzoek van onderwijs, is gekozen voor een brede aanpak om zodoende inzicht te krijgen in verschillende aspecten van de curriculumvernieuwingen.

De centrale vraag was: Wat gebeurt er met de lerende (de student) in een studentgecentreerd veterinair curriculum met substantiële aandacht voor onderwijs in generieke competenties en hoe wordt het ervaren door studenten, docenten en alumni, in het bijzonder de werkcolleges, de onderzoeksstage en de voorbereiding op de professionele praktijk?

\section{Subvragen waren:}

1. Hoe zijn de verschillende aspecten van studentgecentreerd onderwijs, met aandacht voor generieke competenties, in het ontwerp van de nieuwe curricula ondergebracht?

2. Hoe ervaren studenten en docenten de werkcolleges als onderwijsvorm, wat gebeurt er precies tijdens de werkcol- leges en welke factoren zijn van invloed op het leren?

3. Hoe ervaren studenten de onderzoeksstage als onderwijsvorm, wat zijn de sterktes en zwaktes van de onderzoeksverslagen en welke factoren zijn van invloed op het leren tijdens de onderzoeksstage?

4. Hoe hebben alumni hun curriculum ervaren en in welke mate voelden zij zich voorbereid op hun beroepsuitoefening?

Om deze vragen te kunnen beantwoorden zijn zes studies uitgevoerd. Zowel procesgerichte als uitkomstgerichte invalshoeken zijn gehanteerd. Er is gebruik gemaakt van een verscheidenheid aan onderzoeksmethodieken en bronnen, te weten documentanalyse, constructie van een beoordelingsinstrument, meningen en ervaringen van studenten, docenten en afgestudeerden met behulp van vragenlijsten en observatietechnieken.

\section{Conclusies}

De opvallendste conclusies waren:

- Studenten diergeneeskunde percipiëren de werkcolleges als een onderwijsvorm die nuttig is voor hun leren en ze zijn over het algemeen tevreden over de kwaliteit van de docenten en opdrachten. Groepsinteractie gebeurt echter niet in die mate en op die wijze die bedoeld was bij het invoeren van de werkcolleges als onderwijsvorm. De docenten domineren in de geuite verbale interacties. Leergerichte interacties tussen studenten en actieve participatie van studenten zijn belangrijke kenmerken van studentgecentreerd onderwijs. Aandacht zal besteed moeten worden aan verbeteringen van werkcolleges als activerende onderwijsvorm.

- Studenten diergeneeskunde ervaren de onderzoeksstage als zeer positief op nagenoeg alle factoren die van invloed 
zijn op de leerprocessen tijdens de stage. De onderzoekscompetenties die tot uiting komen bij het schrijven van een onderzoeksverslag bleken meetbaar met het ontwikkelde instrument. De begeleiding en het intellectuele en sociale werkklimaat hadden invloed op de kwaliteit van de verslagen en op de algemene tevredenheid met de stage.

- Afgestudeerde dierenartsen van het 'nieuwe' 1995 curriculum voelen zich op verscheidene competenties beter toegerust voor het beroepsveld dan hun collega's van het 'oude' 1982 curriculum. Deze resultaten komen grotendeels overeen met de intenties van de curriculumvernieuwingen. Echter, duidelijke hiaten in de opleiding worden opgemerkt die tevens niet verwoord stonden in de curriculumrapporten zoals (eerstelijns) praktische vaardigheden, praktijkmanagement en alsnog een extra nadruk op communicatievaardigheden.

\section{Aanbevelingen onderwijspraktijk}

Praktische aanbevelingen om de kwaliteit van het diergeneeskundig onderwijs te verhogen zijn:

- Meer praktijkgericht onderwijs (zoals vroege patiënt- en praktijkcontacten in het curriculum, verlenging van het externe onderwijs, specifiek vaardigheden- onderwijs waaronder onderwijs in praktijkmanagement en communicatieve vaardigheden).

- Vergroten van actieve participatie van studenten binnen de werkcolleges door bijvoorbeeld kleinere groepen te formeren en dialoog- en discussievaardigheden te trainen bij zowel studenten als docenten.

- Begeleiders van onderzoeksstage trainen in hun belangrijke begeleiderrol en studenten beter voorbereiden op hun stage.

- Meer longitudinaal samenhangend onderwijs in wetenschappelijke vaardigheden.

\section{Toekomstig onderzoek}

Verder onderzoek is nodig om de bestaande discrepanties te monitoren en te evalueren tussen wat was bedoeld met de curriculumveranderingen (intended curriculum) en hoe het daadwerkelijk tot uiting komt in het curriculum (curriculum in action).

Meer fundamenteel onderzoek zal inzicht moeten bieden in de vraag welke factoren van invloed zijn op de effectiviteit van groepsinteractie in werkcolleges.

Tevens zou diepgaand onderzoek gericht kunnen worden op alumni en op de kloof tussen universiteit en praktijk om zodoende de overgang beter te maken. 